\title{
Pyruvate Dehydrogenase Phosphatase Deficiency: A Cause of Congenital Chronic Lactic Acidosis in Infancy
}

\author{
B. H. ROBINSON ${ }^{(39)}$ AND W. G. SHERWOOD \\ Research Institute and Department of Paediatrics, The Hospital for Sick Children, Toronto, Ontario, Canada
}

\section{Extract}

A male child presented on the first day of life with metabolic acidosis with elevated blood lactate $(15 \mathrm{mM})$, pyruvate $(0.4 \mathrm{mM})$, and free fatty acid $(1.3 \mathrm{mM})$ levels and a blood $\mathrm{pH}$ of 7.16. The severity of the acidosis was diminished by intravenous administration of glucose in large doses and by bicarbonate. On two occasions, when the acidosis was particularly severe, peritoneal dialysis using an acetate buffer was required. Restriction of the dietary intake of saturated fatty acids or treatment with nicotinic acid also appeared to diminish the severity of acidosis. No improvement was achieved by the administration of thiamine or biotin. Tissues taken at postmortem showed normal activity of gluconeogenic enzymes and pyruvate dehydrogenase. The activity of pyruvate dehydrogenase in tissue homogenates preincubated with ATP was reduced by $60-75 \%$ both in liver of the patient and of the controls because of the inactivation of the enzyme by pyruvate dehydrogenase kinase. Addition of $\mathrm{Ca}^{++}$and $\mathrm{Mg}^{++}$to the inactivated enzyme caused a prompt return of the activity to normal in controls but not in the patient. This defect, which was apparent in muscle and liver but not in brain, we attribute to a markedly reduced activity of pyruvate dehydrogenase phosphatase in the patient.

\section{Speculation}

Certain cases of chronic congenital lactic acidosis in infancy may be due to pyruvate dehydrogenase phosphatase deficiency.

Chronic congenital lactic acidosis of infancy is a disease characterized by a persistent elevation of blood pyruvate and lactate $(9,15,16,21)$. In three patients with chronic congenital lactic acidosis, markedly reduced activity of pyruvate dehydrogenase (EC. 1.2.4.1) was reported. In two of these, the defect was localized in the pyruvate decarboxylase (EC. 4.1.1.1) component of the enzyme complex $(8,14)$ and in the third patient in the dehydrolipoyl transacetylase (EC. 2.3.1.12) or the dihydrolipoyl dehydrogenase (EC. 1.6.4.3) component (9).

In this communication, we report a patient with chronic congenital lactic acidosis in whom biochemical investigations on tissue obtained at postmortem revealed a defect in the phosphorylation-dephosphorylation mechanisms controling the overall activity of the pyruvate dehydrogenase complex in the liver and muscle. The postulated defect is correlated with the clinical manifestations of the disease during the life of the patient.

\section{CASE REPORT}

The male patient was born in February 1974 to nonconsanguineous Caucasian parents after an uneventful pregnancy at full term with a birth weight of $3.2 \mathrm{~kg}$. The mother was 27 years old, gravida 3, para 3. A 7-year-old brother was normal. A sister had died at the age of 6 weeks with a chronic metabolic acidosis that had been noted from the first day of life. At birth in our patient the Apgar score was 8 at $1 \mathrm{~min}$, but acidosis developed during the first day of life and the patient was transferred to The Hospital for Sick Children.

He was a well developed newborn with severe tachypnoea of the Kussmaul type, poor peripheral perfusion, hypotonicity, and diminished consciousness. He did not have evidence of cardiopulmonary disease nor hepatomegaly. His biochemical data on admission are shown in Table 1 and indicated a metabolic acidosis associated with elevated levels of blood lactate $(15 \mathrm{mM} \mathrm{N}<2$ $\mathrm{mM})$, pyruvate $(0.4 \mathrm{mM} \mathrm{N}<0.2 \mathrm{mM}), \beta$-hydroxybutyrate $(1.8$ $\mathrm{mM} \mathrm{N}<0.5 \mathrm{mM})$, acetoacetate $(0.36 \mathrm{mM} \mathrm{N}<0.15 \mathrm{mM})$, and alanine $(1.0 \mathrm{mM} \mathrm{N}<0.5)$. The plasma free fatty acid level was elevated; the plasma glucose level was normal. Amino acid analysis of plasma and urine showed no abnormalities other than an elevated alanine level. Gas-liquid chromatography showed no abnormal organic acids to be present in the urine.

Therapy was commenced with an intravenous infusion of sodium bicarbonate (4-5 $\mathrm{mEq} / \mathrm{kg} / \mathrm{hr}$ ) and glucose $(4 \mathrm{mg} / \mathrm{kg} / \mathrm{min})$. The clinical and biochemical parameters did not alter appreciably until the 6th day of life when the rate of glucose infusion was increased to $12 \mathrm{mg} / \mathrm{kg} / \mathrm{min}$. Within $36 \mathrm{hr}$ the plasma ketones had markedly decreased and the ketonuria had disappeared. The blood lactate had fallen from the previous range of $15-20 \mathrm{mM}$ to $6 \mathrm{mM}$. The rate of infusion of both glucose and sodium bicarbonate was reduced. Commercial formula feeds (SMA) were commenced. The infant improved clinically and behaved normally.

During the stable periods of the infant's life, the basal blood lactate level remained in the range of 4-7 $\mathrm{mM}(\mathrm{N}<2 \mathrm{mM})$ and ketonuria was absent. At no time was hypoglycemia apparent. However, intermittent exacerbation of both lactic and ketoacidosis occurred at unpredictable and varying intervals, every 4-12 days, lasting for 3-5 days. When the blood lactate level rose to 9-15 $\mathrm{mM}$, oral bicarbonate therapy $(20-25 \mathrm{mEq} / \mathrm{kg} / 24 \mathrm{hr})$ usually controlled the acidosis. At other times, when the blood lactate level rose to $15-20 \mathrm{mM}$ and the $\beta$-hydroxybutyrate to $2.5-3.5 \mathrm{mM}$, more vigorous therapy was required. It was the episodic nature of this infant's clinical course that made the assessment of the clinical and biochemical effects of therapeutic measures difficult. At the age of 3-4 months, neurologic damage became increasingly evident with intermittent lethargy, irritability, and intermittent generalized seizure activity. The infant did not respond appropriately to stimuli. Death occurred at the age of 6 months.

\section{METHODS}

Lactate (2), pyruvate (3), $\beta$-hydroxybutyrate (4), acetoacetate (5), citrate (6), and $\alpha$-ketoglutarate (7) were measured in whole blood samples extracted 1:1 with $0.6 \mathrm{~N}$ perchloric acid by enzyme spectrophotometric methods. Free fatty acids were measured in plasma by the method of Laurell and Tibbling (20).

Liver, brain, and muscle tissue was obtained $1 \mathrm{hr}$ after death at 
Table 1. Biochemical data on admission

\begin{tabular}{|c|c|c|c|}
\hline & $\begin{array}{l}\mathrm{mEq} / \\
\text { liter }\end{array}$ & & $\begin{array}{l}\mathrm{mEq} / \\
\text { liter }\end{array}$ \\
\hline Plasma & & Blood & \\
\hline Sodium & 134 & $\mathrm{pH}$ & 7.16 \\
\hline Potassium & 4.4 & $\mathrm{pCO}_{2}, \mathrm{~mm} \mathrm{Hg}$ & 11 \\
\hline Chloride & 110 & Urine $\mathrm{pH}$ & 5.2 \\
\hline Blood & & Plasma & \\
\hline Bicarbonate & 3.5 & Glucose, mg/100 ml & 136 \\
\hline Lactate & 15.0 & Free fatty acid, mM & 1.3 \\
\hline Pyruvate & 0.4 & Citrate, $\mathrm{mM}$ & 0.11 \\
\hline$\beta$-Hydroxybutyrate & 1.8 & $\alpha$-Ketoglutarate, $\mathrm{mM}$ & 0.025 \\
\hline Acetoacetate & 0.36 & & \\
\hline Alanine & 1.0 & & \\
\hline
\end{tabular}

autopsy. The tissues were frozen in liquid nitrogen and stored at $-100^{\circ}$ until used for determinations. For the enzyme assays to be listed below small pieces of tissue were thawed, homogenized in 10 volumes ice-cold $0.25 \mathrm{M}$ sucrose, $5 \mathrm{mM}$ Tris- $\mathrm{HCl}$ buffer, $\mathrm{pH} 7.4$, and centrifuged at $600 \times g$ for $10 \mathrm{~min}$ to remove cell debris. Glucose-6-phosphatase was measured by the method of Swanson (30), fructose-1,6-diphosphatase by the method of Pont remoli (24), phosphoenolpyruvate carboxykinase by the method of Roobol and Alleyne (25), and pyruvate carboxylase by the method of Crabtree et al. (12).

For the determination of pyruvate dehydrogenase activity the method of Taylor et al. was used (31). The assay of whole tissue pyruvate dehydrogenase activity was carried out using $300-400 \mathrm{mg}$ freshly thawed tissue homogenized in 10 volumes ice-cold buffer containing $10 \mathrm{mM}$ potassium phosphate, I mM EDTA, $1 \mathrm{mM}$ dithiothreitol, $1 \%$ fatty acid free bovine serum albumin, $\mathrm{pH} 7.4$. Aliquots of $0.1 \mathrm{ml}$ were then added to the main chamber of $10-\mathrm{ml}$ Erlenmeyer flasks containing $0.8 \mathrm{ml}$ assay buffer $(11 \mathrm{mM}$ potassium phosphate, $1.1 \mathrm{mM}$ EDTA, $2.8 \mathrm{mM} \mathrm{MgCl}_{2}, 1.6 \%$ bovine serum albumin (fatty acid free), $1.2 \mathrm{mM}$ dithiothreitol, $0.3 \mathrm{mM}$ pyruvate labeled with $0.12 \mu \mathrm{Ci}\left[1-{ }^{14} \mathrm{C}\right]$ pyruvate $/ \mathrm{ml}$ at $\mathrm{pH} 7.4$ and $\left.37^{\circ}\right)$. The flasks were fitted with plastic inserts holding strips of filter paper $(1 \times 3 \mathrm{~cm})$ saturated with $0.2 \mathrm{ml}$ Hyamine and closed with a rubber stopper. The reaction was stopped after a given time interval by injecting $0.8 \mathrm{ml} 0.08 \mathrm{M}$ citric acid, $0.04 \mathrm{M} \mathrm{Na}_{2} \mathrm{HPO}_{4}$ buffer ( $\mathrm{pH}$ 3.0). After $30 \mathrm{~min}$ of further incubation the filter strips were removed with forceps and placed in $10 \mathrm{ml}$ toluene-ethanol $(9: 1, v / v)$ scintillation fluid and the ${ }^{14} \mathrm{C}$ activity measured in a Beckman liquid scintillation spectrometer.

Preincubations were carried out by warming aliquots of the homogenate to $37^{\circ}$ and adding various effectors (ATP. Ca ${ }^{++}$, and $\mathrm{Mg}^{++}$) in concentrations and for the times given in the text. Aliquots of $0.1 \mathrm{ml}$ were then transferred to the assay system above. The time dependence of this assay system is shown in Figure 1 using control tissue from liver and brain with and without preincubation of the homogenate with ATP. Linearity is evident up to a period of $2 \mathrm{~min}$ under the conditions used.

\section{RESULTS}

\section{BIOCHEMICAL INVESTIGATIONS DURING PATIENT'S LIFE}

Based on the repeatedly observed good therapeutic response to intravenous glucose, a low fat, high carbohydrate diet was introduced which supplied protein $(2.5 \mathrm{~g} / \mathrm{kg} / 24 \mathrm{hr})$ in skim milk with added glucose to provide a total of $80 \mathrm{cal} / \mathrm{kg} / 24 \mathrm{hr}$. This was fed at 2-hour intervals for 20 days. During that time the basal lactate levels remained in the range of $7-9 \mathrm{mM}$. Three moderate exacerbations of the acidosis occurred with lactate levels of the order of $9-12 \mathrm{mM}$.

Then, while continuing this low fat, carbohydrate diet, nicotinic acid was administered orally in increasing doses up to 300 $\mathrm{mg} / 24 \mathrm{hr}$ over a 10-day period. Blockade of endogenous lipolysi: was achieved and was reflected in the fall of the plasma free fatty acid concentration from 0.8 to $0.2 \mathrm{mM}$. The basal blood lactate levels remained in the range of 4-7 mM. Exacerbations of the acidosis did not occur.

Then nicotinic acid therapy was discontinued and corn oil was added to the diet of skim milk and glucose. Six grams corn oil per day added a further $15 \mathrm{cal} / \mathrm{kg} / 24 \mathrm{hr}$. On this diet, the basal lactate level was in the range of $7-11 \mathrm{mM}$. However, several moderate exacerbations of acidosis occurred with blood lactate levels up to $15 \mathrm{mM}$. At these times, reinstitution of intravenous glucose and bicarbonate resulted in a fall in the degree of acidosis. However, on two occasions, the blood lactate rose to the range of $18-25 \mathrm{mM}$ whereupon peritoneal dialysis was instituted with an acetate buffer solution (Plasmalyte 56). This rapidly controlled the acidosis and the blood lactate levels fell to $10-12 \mathrm{mM}$ over the 48 -hr duration of each dialysis. When dialysis was discontinued, glucose and bicarbonate therapy was reintroduced and during the following 4-5 days, the blood lactate levels fell to the range of 3-4 mM.

On three occasions when the modified diet of skim milk, glucose, and corn oil was replaced by SMA oral feeds, a moderate to severe exacerbation of acidosis occurred within 12-24 hr.

Neither thiamine hydrochloride ( $20 \mathrm{mg}$ im for 5 days) nor biotin $(5 \mathrm{mg}$ iv over $12 \mathrm{hr}$ ) produced any change in the basal blood lactate concentration.

\section{POSTMORTEM INVESTIGATION}

The activities of glucose-6-phosphatase, phosphoenolpyruvate carboxykinase, pyruvate carboxylase, and pyruvate dehydrogenase in the liver homogenate were all within the normal range, whereas the activity of fructose-1,6-diphosphatase was elevated Table 2).

Since the enzyme activities measured indicated neither a block in gluconeogenesis nor a block in pyruvate oxidation, the possibility of a defect in the control of pyruvate decarboxylation was investigated. Using tissue homogenates of the patient and controls the pyruvate dehydrogenase activity was measured before and after preincubation with ATP, which is known to inactivate pyruvate dehydrogenase by increasing the activity of the controling enzyme, pyruvate dehydrogenase kinase $(13,14)$. The results of such an experiment are shown in Figure 2. ATP appeared to have the predictable effect in the case of both the patient and the control. Preincubation of liver homogenate for 2 min with $0.2 \mathrm{mM}$ ATP resulted in marked reduction of pyruvate dehydrogenase activity in both the control and the patient tissue, respectively.

After this, the reactivation of pyruvate dehydrogenase was investigated. It is known that $\mathrm{Ca}^{++}$activates pyruvate dehydrogenase phosphatase, an enxyme which converts inactive phosphopyruvate dehydrogenase to its dephosphorylated active form $(13,33)$. It can be seen in the right-hand panel of Figure 2 that addition of

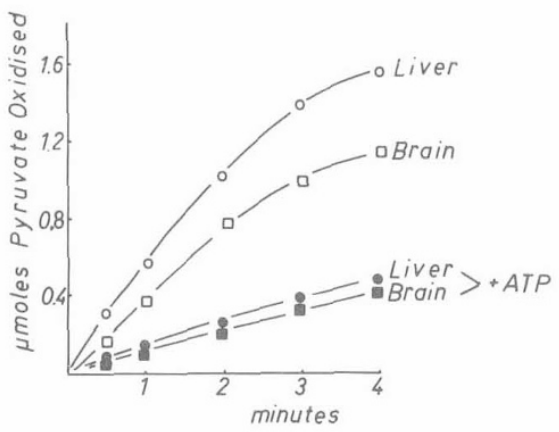

Fig. 1. Time course of micromoles of pyruvate oxidation in liver and brain homogenates. Homogenates of liver and brain $(0.1-\mathrm{ml}$ aliquots) from the patients's tissues were incubated for time periods of up to $4 \mathrm{~min}$ in a medium containing $\left[1-{ }^{14} \mathrm{C}\right]$ pyruvate as described by Taylor et al. (32), and the ${ }^{14} \mathrm{CO}_{2}$ collected after acidification of the incubation medium to $\mathrm{pH}$ 3.0. This experiment was repeated with homogenates which had been preincubated with $0.2 \mathrm{mM}$ ATP for $3 \mathrm{~min}$. 
$\mathrm{mM} \mathrm{Ca}{ }^{++}$to the control liver homogenate resulted in rapid activation of pyruvate dehydrogenase and within 6 min activity as restored almost to that level before inactivation. However, the ddition of $2 \mathrm{mM} \mathrm{Ca}^{++}$to the patient's liver homogenate, as hown in the left-hand panel of Figure 1, resulted in only minimal eactivation.

In Table 3 results of similar studies are shown with homogenates f liver and also with muscle and brain homogenates of both the atient and controls.

In order to determine whether this defect was localized in liver, omogenates of liver, muscle, and brain were incubated under five ets of conditions and the activity of pyruvate dehydrogenase was neasured (Table 3). ATP reduced the activity of pyruvate lehydrogenase in all three tissues in both the patient and in the ontrols. The degree of inactivation was somewhat variable, specially in muscle. The extent of inactivation found in the tissues if the patient was within the range of controls in the liver, although lightly lower in muscle and brain. When $\mathrm{Ca}^{++}(10 \mathrm{mM})$ and

Table 2. Activities of key gluconeogenic enzymes and pyruvate dehydrogenase in liver of patient compared with controls

\begin{tabular}{lccc}
\hline & \multicolumn{3}{c}{$\mu$ mol $/ \mathrm{min} / \mathrm{g}$ liver } \\
\cline { 2 - 4 } & Patient & Controls $^{1}$ & Range \\
\hline Glucose-6-phosphatase & 1.70 & $1.77 \pm 0.16$ & $(1.36-2.14)$ \\
$\begin{array}{l}\text { Fructose-1,6-diphosphatase } \\
\text { Phosphoenolpyruvate }\end{array}$ & 3.2 & $1.72 \pm 0.42$ & $(0.91-3.21)$ \\
$\quad$ carboxykinase & 0.78 & $0.97 \pm 0.08$ & $(0.79-1.32)$ \\
$\begin{array}{l}\text { Pyruvate carboxylase } \\
\text { Pyruvate dehydrogenase }\end{array}$ & 0.61 & $0.66 \pm 0.02$ & $(0.61-0.71)$ \\
& 0.80 & $0.59 \pm 0.07$ & $(0.45-0.76)$
\end{tabular}

${ }^{1} V$ alues for controls are given as the mean \pm SEM. Control values are from two biopsy specimens taken from patients undergoing liver surgery and from four specimens taken at 1-2 hr postmortem.
$\mathrm{Mg}^{++}(10 \mathrm{mM})$ were added to reactivate the pyruvate dehydrogenase, activity in the liver of controls was restored in 5 min from $34 \%$ of the original activity to $83 \%$. However, with the patient's liver homogenate the degree of reactivation was from $39.9 \%$ to $44.1 \%$, indicating a markedly reduced ability of the patient to reactivate the enzyme. A similar effect was seen in muscle. Although reactivation in this case was variable in controls, it was minimal in the tissues of the patient. An alternative method to adding $\mathrm{Ca}^{++}$ and $\mathrm{Mg}^{++}$of stimulating conversion of inactive to the active form of this enzyme is by the removal of ATP through the hexokinase reaction. Addition of glucose and hexokinase after inactivation with ATP gave consistent reactivation in controls, but only a very small reactivation in the patient. Addition of $\mathrm{Ca}^{++}$and $\mathrm{Mg}^{++}$to homogenates in the absence of ATP had little effect on the activity of pyruvate dehydrogenase in any of the tissues. In brain, however, although one only control specimen was available, inactivation and reactivation occurred both in patient and control to a similar extent.
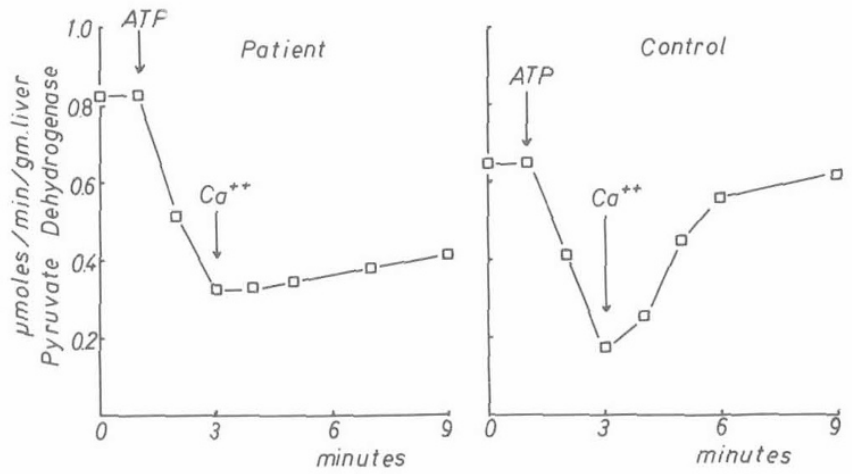

Fig. 2. Activity of pyruvate dehydrogenase in homogenates of the liver of the patient and a control on incubation with ATP and $\mathrm{Ca}^{++}$. See text for details of experiment.

Table 3. Pyruvate dehydrogenase activity in liver, brain, and muscle of patient compared with controls ${ }^{1}$

Pyruvate dehydrogenase activity, $\mathrm{nmol} / \mathrm{min} / \mathrm{g}$ liver

(d)

(a) No additions

(b)

ATP

(c)

$\mathrm{ATP}+\mathrm{Ca}^{++}+\mathrm{Mg}^{++}$

ATP + hexokinase glucose

(e) $\mathrm{Ca}^{++}+\mathrm{Mg}^{++}$

\begin{tabular}{|c|c|c|c|c|c|}
\hline \multicolumn{6}{|l|}{ Muscle } \\
\hline Control I & 1,041 & 197 & 455 & 914 & 1,045 \\
\hline Control 2 & 1,167 & 476 & 1,025 & 1,171 & 1,340 \\
\hline Control 3 & 1,298 & 547 & 872 & 1,243 & 1,421 \\
\hline \multicolumn{6}{|l|}{ Patient } \\
\hline Expt.i & 1,120 & 606 & 620 & 656 & 1,610 \\
\hline Expt.ii & 1,336 & 694 & 592 & 721 & 1,330 \\
\hline \multicolumn{6}{|l|}{ Brain } \\
\hline Control & 430 & 186 & 362 & & 484 \\
\hline Patient & 605 & 388 & 505 & & 606 \\
\hline \multicolumn{6}{|l|}{ Liver } \\
\hline Control I & 790 & 215 & 690 & & 715 \\
\hline Control 2 & 755 & 167 & 592 & & 790 \\
\hline Control 3 & 715 & 205 & 645 & & 800 \\
\hline Control 4 & 630 & 306 & 519 & & 705 \\
\hline Control 5 & 731 & 362 & 569 & & 698 \\
\hline \multicolumn{6}{|l|}{ Patient } \\
\hline Expt.i & 805 & 325 & 374 & & 801 \\
\hline Expt.ii & 781 & 341 & 356 & & 671 \\
\hline Expt.iii & 846 & 315 & 341 & & 631 \\
\hline
\end{tabular}

${ }^{1}$ Pyruvate dehydrogenase activity was determined in tissue homogenates as described in Reference 31 after the following preincubations; (a) no additions; (b) plus $0.2 \mathrm{mM}$ ATP for $3 \mathrm{~min}$; (c) plus $0.2 \mathrm{mM} \mathrm{ATP}$ for $3 \mathrm{~min}$ followed by $10 \mathrm{mM} \mathrm{Ca}^{++}$and $10 \mathrm{mM} \mathrm{Mg}^{++}$; (d) plus $0.2 \mathrm{mM} \mathrm{ATP} \mathrm{for} 3 \mathrm{~min}$ followed by $5 \mathrm{mM}$ glucose and $2 \mathrm{U}$ hexokinase for $3 \mathrm{~min}$; (e) plus $10 \mathrm{mM} \mathrm{Mg} \mathrm{Mg}^{++}$and $10 \mathrm{mM} \mathrm{Ca}^{++}$for $3 \mathrm{~min}$. 


\section{DISCUSSION}

\section{CLINICAL AND CHEMICAL STUDIES DURING LIFE}

The clinical history, the course of the disease, and the laboratory data obtained during life in this patient provide some very pertinent clues when one considers the etiology of chronic congenital lactic acidosis. That the disease is familial is shown in this case by the fact that a female sib of the patient died at 6 weeks of age with a severe lactic acidosis. Both lactate and pyruvate were elevated, which indicated that pyruvate was not being metabolized and although the lactate to pyruvate ratio was abnormally high, there was no apparent hypoxia. The absence of hypoglycemia at any point during the course of the patient's disease suggested that the lactic acidosis was not due to a primary block in the gluconeogenic pathway such as is seen in pyruvate carboxylase deficiency (10), fructose-1,6-diphosphatase deficiency (1), or type I glycogen storage disease (glucose-6-phosphatase deficiency) (26). The onset from birth, the severity of the acidosis, and the absence of a raised plasma $\alpha$-ketoglutarate or citrate level made the possibility of Leigh's disease unlikely $(17,36)$. The absence of abnormal urinary organic acids ruled out the possibility that the lactic acidosis was secondary to a block in propionate or methylmalonate metabolism.

The finding of elevated plasma free fatty acid levels in this patient raised the possibility of a defect in fat metabolism, but this was deemed unlikely, at least in liver, because of the presence of ketone bodies in the plasma which indicated that fatty acids were being oxidized. Nevertheless, it was observed that a high dietary fat intake, especially of saturated fatty acids, made the acidosis worse, whereas a high carbohydrate intake seemed to correct the acidosis. Unsaturated fats appeared to be tolerated better than saturated fats. Reduction of circulating free fatty acid levels by nicotinic acid therapy appeared to have a beneficial effect though the lactic acidosis was still evident. Summarizing this information, we felt that although a plentiful dietary supply of saturated fatty acids had an adverse effect on the acidosis, a primary defect in the catabolism of fat was unlikely to be the cause of the lactic acidosis.

\section{POSTMORTEM STUDIES}

The finding of normal activities of the key gluconeogenic enzymes in the liver of the patient confirmed our suspicion that a primary block did not exist in the gluconeogenic pathway. The initial finding of adequate pyruvate dehydrogenase activity was at first disconcerting since a distinct possibility existed of a defect in this enzyme, such as in the case described by Blass et al. (8). However, since pyruvate dehydrogenase is a multienzyme complex, the overall activity of which is closely controlled by a phosphorylation-dephosphorylation mechanism $(22,23)$, we felt that a defect in this control system might be a cause of chronic lactic acidosis.

Phosphorylation (and inactivation) of pyruvate dehydrogenase is catalyzed by a specific kinase, which requires magnesium ions and ATP, and which may be subject to inhibition by high concentrations of pyruvate or ADP (Fig. 3). Conversion of pyruvate dehydrogenase phosphate back to the active pyruvate dehydrogenase is catalyzed by a specific phosphatase requiring the divalent metal ions, $\mathrm{Mg}^{++}$and $\mathrm{Ca}^{++}(13,33)$. This regulatory system has been demonstrated to be active in muscle, brain, liver.

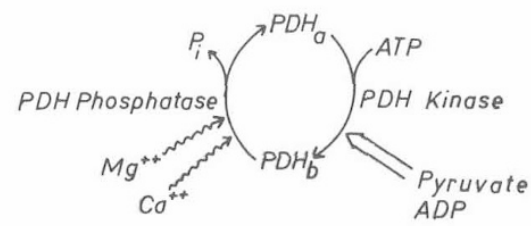

Fig. 3. Diagram to show activators and inhibitors of pyruvate dehydrogenase interconversion. Squiggly arrows indicate activation, thick arrows denote inhibition. kidney, and adipose tissue $(13,22,32,33,35)$, but a theory or concept as to how the system operates to modulate pyruva dehydrogenase activity in vivo has only recently been proposed ( 3 34).

In order to explain the change from the active to the inacti form of pyruvate dehydrogenase as a result of the transition from fed to a fasted state, it has been proposed that on fasting, free fat acid levels increase, thus leading to increased tissue levels of lor chain acyl-CoA thioesters, which inhibit the mitochrondrial ad nine nucleotide translocase system $(23,28)$ and the citrate-tran porting system $(11,18)$, whereupon the intramitochondrial co centrations of both citrate and ATP rise. This has two effects: firs both these compounds effectively chelate $\mathrm{Ca}^{++}$and $\mathrm{Mg}^{++}$an prevent them from activating the phosphatase. Second, th elevated level of ATP ensures that the kinase brings abot inactivation of the pyruvate dehydrogenase complex. When fatt acyl-CoA levels fall, the intramitochondrial ATP and citrate leve fall, $\mathrm{Ca}^{++}$and $\mathrm{Mg}^{++}$are released, and the phosphatase restore the inactive pyruvate dehydrogenase to the active form again.

We have demonstrated in the patient that pyruvate dehydrogen ase phosphatase is defective in muscle and liver, having a estimated activity between 0 and $10 \%$ of normal. The fact tha some activity of the phosphatase exists explains why the pyruvat dehydrogenase isolated from postmortem tissues appeared to $b$ almost fully activated. Since postmortem ATP levels in all tissue fall rapidly to extremely low levels, inactivity of pyruvate dehydro genase kinase would result. The low activity of the phosphatase it this patient would them be able to dephosphorylate the enzyme anc restore full activity. However, "in vivo", one would expect the predominance of the kinase and the deficiency of the phosphatase to keep the pyruvate dehydrogenase complex in the inactive form Resulting from this inability to fully oxidize the available pyruvate would be an elevation of pyruvate and lactic levels resulting ir chronic lactic acidosis. Any circumstance leading to elevation of issue fatty acyl-CoA esters would make the pyruvate dehydrogenase enzyme complex more inactive, a situation that concurs with our observations that the lactic acidosis was exacerbated by dietary fatty acids and relieved by reduction of circulating fatty acids and use of nicotinic acid therapy.

There are two important clinical points arising from consideration of the biochemical aspects of lactic acidosis. It has been reported in two cases of congenital lactic acidosis that transfusion of patient with citrated blood caused a severe bout of acidosis (19. 27). Consideration of the effect of citrate on pyruvate dehydrogenase phosphatase activity dictates that any activity in this enzyme would be drastically reduced by removing the activators $\mathrm{Ca}^{++}$and $\mathrm{Mg}^{++}$. If this enzyme is already defective in activity, citrate would have the effect of putting the pyruvate dehydrogenase complex completely in the inactive form. Also, acetate has been shown in vitro to activate the enzyme by inhibiting the kinase (31), which might explain why peritoneal dialysis against acetate buffer in the patient was successful in alleviating the acidosis.

\section{REFERENCES AND NOTES}

I. Bakker, H. D., deBree, P. K., Ketting, D., Van Sprang, F. J., and Wadman, S K.: Fructose-1,6-diphosphatase deficiency: Another enzyme defect which can present itself with the clinical features of "Tyrosinosis". Clin. Chim. Acta, 55: 41 (1974).

2. Bergemeyer, H. U., and Bernt, E.: L(+) Lactate. In: H. U. Bergemeyer: Methods in Enzymatic Analysis p. 271 (Academic Press, New York, 1965).

3. Bergemeyer, H. U., and Bernt. E.: Pyruvate. In: H. U. Bergemeyer: Methods in Enzymatic Analysis, p. 253 (Academic Press, New York, 1965).

4. Bergemeyer, H. U., and Bernt, E.: D(-) $\beta$-Hydroxybutyrate. In: H. U. Bergemeyer: Methods in Enzymatic Analysis, p. 459 (Academic Press, New York, 1965).

5. Bergemeyer, H. U., and Bernt, E.: Acetoacetate. In: H. U. Bergemeyer: Methods in Enzymatic Analysis, p. 454 (Academic Press, New York, 1965).

6. Bergemeyer, H. U., and Bernt, E.: Citrate and isocitrate. In: H. U. Bergemeyer: Methods in Enzymatic Analysis, p. 318 (Academic Press, New York, 1965).

7. Bergemeyer, H. U., and Bernt, E.: $\alpha$-Oxoglutarate. In: H. U. Bergemeyer: Methods in Enzymatic Analysis, p. 324 (Academic Press, New York, 1965).

8. Blass, J. P., Kark, P., and Engel, W. K.: Clinical studies of a patient with pyruvate decarbosylase deficiency. Arch. Neurol., 25: 449 (1971). 
9. Blass, J. P., Schulman, J. D., Young, D. S., and Hom, E.: An inherited defect affecting the tricarboxylic acid cycle in a patient with congenital lacticacidosis. J. Clin. Invest., 51: 1845 (1972).

0. Brunette, M. G., Delvin, E., Hazel, B. and Scriver, C. R.: Thiamine responsive lactic acidosis in a patient with deficient low $\mathrm{Km}$ pyruvate carboxylase activity in liver. Pediatrics, 50: 702 (1972).

1. Cheema-Dhadli, S., and Halperin, M. L.: The role of the mitochondrial citrate transporter in the regulation of fatty acid synthesis: Effect of fasting and diabetes. Can. J. Biochem., 51: 1542 (1973).

12. Crabtree, B., Higgins, S. J., and Newsholme, E. A.: The activities of pyruvate carboxylase, phosphoenolpyruvate carboxylase and fructose-1,6-diphosphatase in muscles from vertebrates and invertebrates. Biochem J 130.391 (1972).

13. Denton, R. M., Randle, P. J., and Martin, B. R.: Stimulation by calcium ions of pyruvate dehydrogenase phosphate phosphatase. Biochem. J., 128: 161 (1972).

14. Farrel, D. F., Clark, A. F., Scott, C. R., and Wennberg, R. P.: Absence of pyruvate decarboxylase activity in man: A cause of congenital lacticacidosis. Science, 187: 1082 (1975).

15. Gautier, E.: Lacticacidosis in infancy. Helv. Med. Acta, 35: 423 (1969)

16. Greene, H. L., Schubert, W. K., and Hug, G.: Chronic lactic acidosis of infancy. J. Pediat. 76: 853 (1970).

17. Grover, W. D., Averdach, V. H., and Patel, M. S.: Biochemical studies and therapy in subacute necrotising encephalopathy (Leigh's syndrome). J. Pediat., 81: 39 (1972)

18. Halperin, M. L., Robinson, B. H., and Fritz, I. B.: Effects of palmitoyl CoA on citrate and malate transport by rat liver mitochondria. Proc. Nat. Acad. Sci. U. S. A., 69: 1003 (1972).

19. Israels, S., Haworth, J. C., Gourley, B., and Ford, J. D.: Chronic acidosis due to an error in lactate and pyruvate metabolism. Pediatrics, 34:346 (1964).

20. Laurell, S., and Tibbling, G.: Colorimetric microdetermination of free fatty acids in plasma. Clin. Chim. Acta, 16: 57 (1967).

21. Lie, S. O., Löken, A. C., Stromme, J. H., and Aagenaes, O.: Fatal congenital lacticacidosis in two siblings. I. Acta Paediat. Scand. 60: 129 (1971).

22. Linn, T. C., Pettit. F. H., Hucho, F., and Reed. L. J.: $\alpha$-Keto acid dehydrogenase complexes. XI. Comparative studies of regulatory properties of the pyruvate dehydrogenase complexes from kidney, heart, and liver mitochondria. Proc. Nat. Acad. Sci. U. S. A.. 64: 227 (1969).

23. Morel, F., Lauquin, G., Lunardi, J., Duszynski, J., and Vignais, P. V.: An appraisal of the functional significance of the inhibitory effect of long chain acyl-CoA's on mitochondrial transports. Fed. Eur. Biochem. Soc. Lett., 39: 133 (1974).

24. Pontremoli, S.: Fructose-1,6-diphosphatase. Methods Enzymol. 9: 625 (1966).

25. Roobol, A.. and Alleyne, G. A. O.: Regulation of renal gluconeogenesis by calcium ions, hormones and adenosine, cyclic 3'-5' monophosphate. Biochem.

Copyright (c) 1975 International Pediatric Research Foundation, Inc.
J., 134: $157(1973)$

26. Sadeghi-Nejad, A., Presente, E., Binkienica, A., and Senior, B.: Studies in Type I glycogenosis of the liver. J. Pediat., 85: 49 (1974).

27. Sharer, K.. Marty, A., Muhlethaler, J. P.: Chronic congenital lactic acidosis. Helv. Paediat. Acta, 23: 107 (1968).

28. Shrago, E., Shug, A., Elson, C., Spennetta, T., and Croshy, C.: Regulation of metabolite transport in rat and guinea pig liver mitochondria by long chain fatty acyl coenzyme A esters. J. Biol, Chem., 249: 5269 (1974).

29. Skrede, S., Stromme, J. H., Stokke, O.. Lie, S. O.. and Eldjarn, L.: Fatal congenital lacticacidosis in two siblings. II. Acta Paediat. Scand., 60: 138 (1971).

30. Swanson, M.: Glucose-6-phosphatase from liver. Methods Enzymol., 2: 541 (1955).

31. Taylor, S. I., Mukherjee, C., and Jungas, R. L.: Studies on the mechanism of activation of adipose tissue pyruvate dehydrogenase by insulin. J. Biol. Chem.. 248: 73 (1973).

32. Taylor, W. M., and Halperin, M. L.: Regulation of pyruvate dehydrogenase in muscle. J. Biol. Chem. 248: 6080 (1973).

33. Wieland, O. H., Patselt, C., and Löffler, G.: Active and inactive forms of pyruvate dehydrogenase in rat liver: Effect of starvation and refeeding and of insulin treatment on pyruvate dehydrogenase interconversion. Eur. J. Biochem., 26: 426 (1972).

34. Wieland, O. H., and Portenhauser, R.: Regulation of pyruvate dehydrogenase interconversion in rat liver mitochondria as related to the phosphorylation state of intramitochondrial adenine nucleotides. Eur. J. Biochem., 45: 577 (1974).

35. Wieland, O. H., Siess, E. A., Weiss, L., Löffler, G., Patzelt, C., Portenhauser, R., Hartmann, J., and Schirmann, A.: Regulation of the mammalian pyruvate dehydrogenase complex by covalent modification. Symp. Soc. Exp. Biol., 27: 371 (1973)

36. Worsely, H. E., Brookfield, R. W., Elwood, J. S., Noble, R. L., and Taylor, W. H.: Lactic acidosis with necrotising encephalopathy in two sibs. Arch. Dis. Childhood, 40: 492 (1965).

36. We thank Dr. M. L. Halperin, Dr. W. Balfe, Dr. G. W. Chance, Dr. E. Marliss, Dr. N. Howard, and Dr. A. Sass-Kortsak for helpful discussion.

37. Dr. W. G. Sherwood is in receipt of a fellowship from the Canadian Medical Research Council.

38. This work was supported by the Medical Research Council of Canada and the Weston Foundation.

39. Requests for reprints should be addressed to: B. H. Robinson, M.D., Research Institute, The Hospital for Sick Children, 555 University Ave., Toronto, Ontario, M5G IX8 (Canada).

40. Accepted for publication August 15, 1975

Printed in U.S.A

\section{Corrigendum}

The Abstracts of the 13th and 14th Annual Meetings of the European Society for Paediatric Endocrinology were published in the August, 1974 issue of this Journal.

Because of a printing error, the headings of the two groups of abstracts were transposed which resulted in the abstracts of the 14th Annual Meeting in Berlin (pages 666-679) appearing under the heading of the 13th Annual Meeting in Paris and, conversely, the abstracts of the 13th Annual Meeting in Paris (pages 680-692) appearing under the heading of the 14th Annual Meeting in Berlin.

Additionally, the heading "Read by Title" mistakenly preceded Abstract 45 on page 673 instead of in its correct position preceding Abstract 45 on page 687 .

The Publisher sincerely regrets these errors. 